\title{
Isolation and complete genome sequence of the thermophilic Geobacillus sp. 12AMOR1 from an Arctic deep-sea hydrothermal vent site
}

\author{
Juliane Wissuwa ${ }^{1,2}$, Runar Stokke ${ }^{1,2^{*}}$, Anita-Elin Fedøy ${ }^{1,2}$, Kjersti Lian ${ }^{3}$, Arne Oskar Smalås ${ }^{3}$ and Ida Helene Steen ${ }^{1,2}$
}

\begin{abstract}
Members of the genus Geobacillus have been isolated from a wide variety of habitats worldwide and are the subject for targeted enzyme utilization in various industrial applications. Here we report the isolation and complete genome sequence of the thermophilic starch-degrading Geobacillus sp. 12AMOR1. The strain 12AMOR1 was isolated from deep-sea hot sediment at the Jan Mayen hydrothermal Vent Site. Geobacillus sp. 12AMOR1 consists of a $3,410,035$ bp circular chromosome and a 32,689 bp plasmid with a $\mathrm{G}+\mathrm{C}$ content of $52 \%$ and $47 \%$, respectively. The genome comprises 3323 protein-coding genes, 88 tRNA species and 10 rRNA operons. The isolate grows on a suite of sugars, complex polysaccharides and proteinous carbon sources. Accordingly, a versatility of genes encoding carbohydrate-active enzymes (CAZy) and peptidases were identified in the genome. Expression, purification and characterization of an enzyme of the glycoside hydrolase family 13 revealed a starch-degrading capacity and high thermal stability with a melting temperature of $76.4^{\circ} \mathrm{C}$. Altogether, the data obtained point to a new isolate from a marine hydrothermal vent with a large bioprospecting potential.
\end{abstract}

Keywords: Thermophile, Geobacillus, Enzymes, Bioprospecting

\section{Introduction}

In 2001 the genus Geobacillus was proposed by Nazina et al. [1] to distinguish it from the genus Bacillus. Bacteria of the genus Geobacillus have been isolated from diverse marine and terrestrial habitats such as oil wells [2], cool soils like from Bolivian Andes [3], sediments from Mariana Trench [4] and deep sea hydrothermal vents [5]. Surprisingly, these thermophiles can be isolated from cold environments from different geographical regions in such large quantities that it speaks against a "contamination" from hot environments, which have been described as paradox [6]. The influence of direct heating action of the sun upon the upper soil layers and heat development due to putrefactive and fermentative processes of mesophiles could give an explanation for their abundance [7, 8]. To our knowledge, Geobacillus

\footnotetext{
* Correspondence: Runar.Stokke@uib.no

${ }^{1}$ Centre for Geobiology, University of Bergen, N-5020 Bergen, Norway

${ }^{2}$ Department of Biology, University of Bergen, N-5020 Bergen, Norway

Full list of author information is available at the end of the article
}

has not been isolated from an Arctic marine habitat. As of June 2015, 37 Geobacillus genomes have been deposited in GenBank. Due to the development of next generation sequencing the number of new sequenced genomes (17) has been almost doubled in the last one and a half years. Of all Geobacillus genomes, 13 have been described as complete, whilst the other 24 genomes have been deposited as drafts. The genus exhibits a broad repertoire of hydrolytic and modifying enzymes and is therefore a valuable resource for biocatalysts involved in biotechnological processes with accelerated temperatures $[9,10]$. The application of thermophilic microorganisms or enzymes in biotechnology gives advantage in enhancing biomass conversion in a variety of biotechnical applications; it minimizes contamination and can reduce the process costs [11]. Diverse Geobacillus strains comprise an arsenal of complex polysaccharide degrading enzymes such as for lignocellulose [12]. Other Geobacillus strains are able to degrade a broad range of alkanes $[13,14]$. Up to now a multiplicity of patents 
derived from the genus comprises restriction nucleases, DNA polymerases, $\alpha$-amylases, xylanase, catalase, lipases and neutral protease among others (EP 2392651, US2011020897, EP2623591, US2012309063, KR100807275 [15, 16]). The glycoside hydrolase group 13 (GH13) $\alpha$-amylases are well studied enzymes which have a broad biotechnological application, for example for bioethanol production, food processing or in textile and paper industry [17]. Due to the broad application of $\alpha$-amylases there is a focus of interest to identify novel $\alpha$-amylases for new and improved applications in biotechnology. In addition to functional screening for enzyme activity, genome investigation is a valuable tool to identify potential biocatalysts. Here we present the isolation and metabolic features of Geobacillus sp. 12AMOR1 (DSM 100439) together with the description of the complete genome and its annotation.

\section{Organism information}

\section{Classification and features}

Geobacillus sp. strain 12AMOR1 was isolated from a $90^{\circ} \mathrm{C}$ hot deep-sea sediment sample collected in July of 2012 from the Arctic Jan Mayen Vent Field (JMVF). The sample was collected using a shovel box connected to a Remote Operating Vehicle (ROV) at a water depth of $470 \mathrm{~m}$. The detailed description of the JMVF site is described elsewhere $[18,19]$.

The bacterium was isolated at $60^{\circ} \mathrm{C}$ on Archaeoglobus medium agar plates [20] pH 6.3 containing $1 \%$ Starch (Sigma Aldrich) at the attempt to screen for starch degraders. Genomic DNA of isolates was extracted using Fas$\mathrm{tDNA}^{\circ}$ Spin Kit for Soil (MP). The partial 16S rRNA gene was amplified by PCR using Hot Star Plus (QIAGEN) and following universal primers B8f (5' AGAGTTTGATCC TGGCTCAG) [21] and Un1391r (5’ GACGGGCGGTG

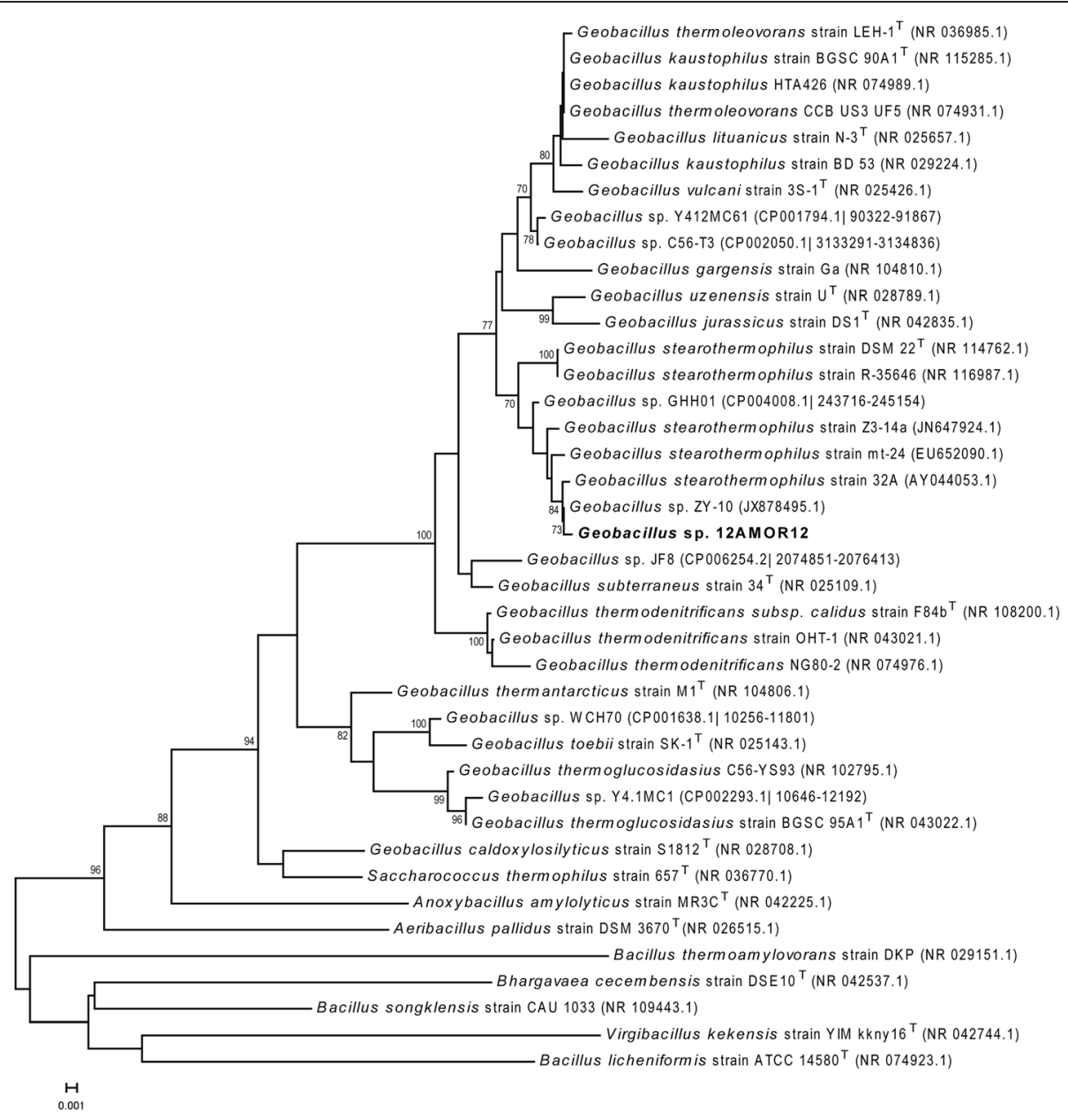

Fig. 1 Phylogenetic tree showing the position of Geobacillus strain 12AMOR1 relative to the other strains of Geobacillus based on 16S rRNA. The Neighbor-Joining tree was built from 1374 aligned positions of the 16S rRNA gene sequences and derived based on the Tamura 3-parameter as preferred model and gamma distribution (shape parameter $=1$ ) for modeling rates variation among sites using MEGA6. Bootstrap values above 70, expressed as percentage of 1000 replicates, are shown at branch points. Bar: 0.01 substitutions per nucleotide position. Bacillus songklensis strain CAU 1033 (NR_109443.1), Bhargavaea cecembensis strain DSE10 (NR_042537.1), Bacillus licheniformis strain ATCC 14580' (NR_074923.1), Virgibacillus kekensis strain YIM kkny16 (NR_042744.1) and Bacillus thermoamylovorans strain DKP (NR_029151.1) was used as outgroup 


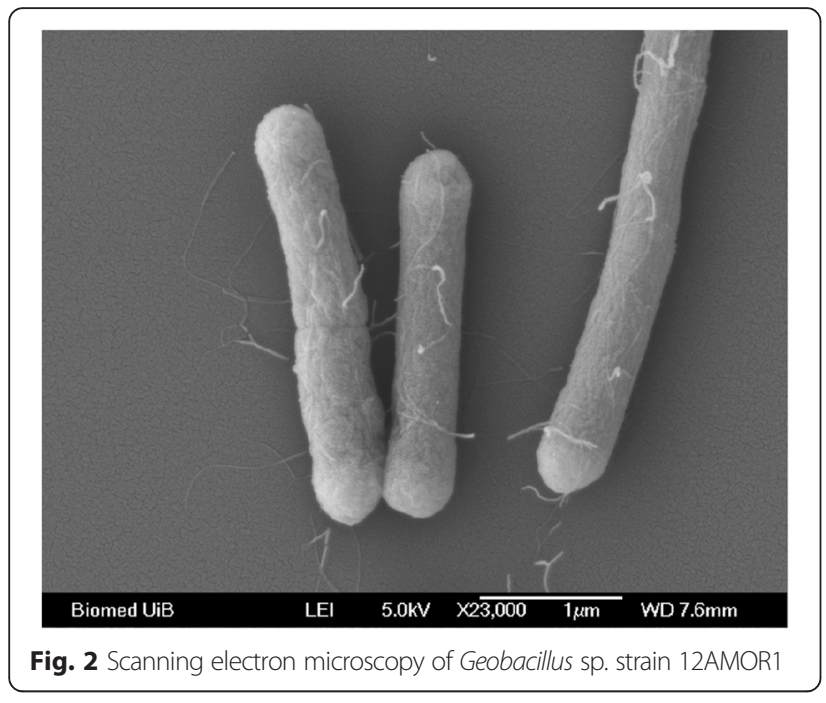

WGTRCA) [22]. The preliminary partial 16S rRNA gene fragment of strain 12AMOR1 has been analyzed using the megablast algorithm in the standalone blastn [23] against $16 \mathrm{~S}$ ribosomal RNA (Bacteria and Archaea database). The partial 16S rRNA gene shared $98 \%$ sequence identity with the strains G. stearothermophilus DSM $22^{\mathrm{T}}$ (NR_114762.1) and R-35646 (NR_116987.1), as well as to other Geobacillus species: Geobacillus subterraneus strain $34^{\mathrm{T}}$ (NR_025 109.1), Geobacillus zalihae strain NBRC $101842^{\mathrm{T}}$ (NR_114 014.1), Geobacillus thermoleovorans strain BGSC $96 \mathrm{~A}^{\mathrm{T}}$ (ref|NR_115286.1), Geobacillus thermocatenulatus strain BGSC $93 \mathrm{Al}^{\mathrm{T}}$ (NR_043020.1), Geobacillus vulcani strain 3S-1 ${ }^{\mathrm{T}}$ (NR_025426.1) and Geobacillus kaustophilus strain BGSC 90A1 ${ }^{\mathrm{T}}$ (NR_115285.1) (Additional file 1). The genome of Geobacillus sp. 12AMOR1 encoded 10 genes for $16 \mathrm{~S}$ rRNA whereby blastn analysis [23] revealed small differences in top hits towards multiple Geobacillus strains.

Table 1 Classification and general feature of Geobacillus sp. strain 12AMOR1 according to the MIGS recommendations

\begin{tabular}{|c|c|c|c|}
\hline MIGS ID & Property & Term & Evidence code \\
\hline & Classification & Domain Bacteria & TAS [55] \\
\hline & & Phylum Firmicutes & $\operatorname{TAS}[56,57]$ \\
\hline & & Class Bacilli & $\operatorname{TAS}[58,59]$ \\
\hline & & Order Bacillales & $\operatorname{TAS}[60,61]$ \\
\hline & & Family Bacillaceae & TAS $[61,62]$ \\
\hline & & Genus Geobacillus & $\operatorname{TAS}[1,7,29]$ \\
\hline & & Species Geobacillus sp. & IDA \\
\hline & & Strain 12AMOR1 & IDA \\
\hline & Gram stain & Positive & IDA \\
\hline & Cell shape & Rod & IDA \\
\hline & Motility & Motile & IDA \\
\hline & Sporulation & Spore forming & IDA \\
\hline & Temperature range & $40-70{ }^{\circ} \mathrm{C}$ & IDA \\
\hline & Optimum Temperature & $60^{\circ} \mathrm{C}$ & IDA \\
\hline & $\mathrm{pH}$ range, optimum & $5.5-9.0 ; 6.5-8.0$ & IDA \\
\hline & Carbon sources & $\begin{array}{l}\text { starch, yeast extract, lactose, galactose, fructose, } \\
\text { lactate, acetate, dextrin }\end{array}$ & IDA \\
\hline MIGS-6 & Habitat & Marine, hydrothermal sediment & IDA \\
\hline MIGS-6.3 & Salinity & $0-5 \%$ & IDA \\
\hline MIGS-22 & Oxygen requirement & Aerobic & IDA \\
\hline MIGS-15 & Biotic relationship & Free-living & IDA \\
\hline MIGS-14 & Pathogenicity & Non-pathogen & NAS \\
\hline MIGS-4 & Geographic location & Troll Wall vent, Arctic Mid-Ocean ridge & IDA \\
\hline MIGS-5 & Sample collection & July 2012 & IDA \\
\hline MIGS-4.1 & Latitude & $71.29665 \mathrm{~N}$ & IDA \\
\hline MIGS-4.2 & Longitude & $5.773133 \mathrm{~W}$ & IDA \\
\hline MIGS-4.3 & Depth & $470 m$ & IDA \\
\hline
\end{tabular}

Evidence codes - IDA Inferred from Direct Assay, TAS Traceable Author Statement (i.e., a direct report exists in the literature), NAS Non-traceable Author Statement (i.e., not directly observed for the living, isolated sample, but based on a generally accepted property for the species, or anecdotal evidence). These evidence codes are from the Gene Ontology project [63] 
The 16S rRNA gene GARCT_01776 was identical to the partial sequence obtained by PCR mentioned above, and thus, the whole 16S rRNA gene GARCT_01776 was used for the phylogenetic analysis.

A phylogenetic tree was constructed from aligning the 16S rRNA gene GARCT_01776 with 16S rRNA genes from selected strains and species from the same genus using MUSCLE [24, 25] and Neighbor-Joining algorithm incorporated in MEGA 6.06 [26]. The 16S rRNA from Geobacillus sp. 12AMOR1 grouped together with Geobacillus sp. ZY-10 and G. stearothermophilus strain 32A, Z3-14a and mt-24 (Fig. 1). Interestingly, within the subcluster of G. stearothermophilus, the isolate 12AMOR1 and herein before mentioned strains were grouped apart from the type strain G. stearothermophilus DSM $22^{\mathrm{T}}$. To further evaluate how closely related the new isolate was to existing species of Geobacillus, a digital DNA-DNA hybridization (DDH) [27] was performed using the complete genomes of 13 Geobacillus species listed in Additional file 2. DDH estimations below $70 \%$ suggested that Geobacillus sp. 12AMOR1 belonged to a new species. The level of relatedness by DDH estimations using formula 2 (identities/HSP length) ranged from 21.5 to $41.5 \%$ between the isolate and different Geobacillus species. Geobacillus sp. 12AMOR1 is a Gram-positive [28], spore-forming, motile, facultative anaerobic rod. The cells are in average $0.5-0.7 \mu \mathrm{m}$ in width and between 1.8 and $4.5 \mu \mathrm{m}$ long. In addition, cells forming long filamentous chains were observed by microscopy. The cells were peritrichous flagellated (Fig. 2) consistent with previously observation of Geobacilli $[1,29]$. Terminal ellipse shaped spores was observed.

Table 2 Genome sequencing information

\begin{tabular}{lll}
\hline MIGS ID & Property & Term \\
\hline MIGS-31 & Finishing quality & Finished \\
MIGS-28 & Libraries used & Pacific Biosciences 10 kb library \\
MIGS-29 & Sequencing platform & PacBio \\
MIGS-31.1 & Fold coverage & $88 x$ \\
MIGS-30 & Assemblers & Hierarchical Genome Assembly \\
& & Process (HGAP) v2 \\
MIGS-32 & Gene calling method & Prodigal \\
& Locus tag & GARCT, pGARCT \\
& Genebank ID & Chromosme CP011832 \\
& & Plasmid CP011833 \\
& Genebank date of release & June 15, 2015 \\
& BioProject ID & PRJNA277925 \\
& GOLD ID & Gp0115795 \\
MIGS-13 & Source Material Identifier & DSM 100439 \\
& Project relevance & Bioprospecting \\
\hline
\end{tabular}

Table 3 Summary of genome: one chromosome and one plasmid

\begin{tabular}{lcll}
\hline Lable & Size $(\mathrm{Mb})$ & Topology & RefSeq ID \\
\hline Chromosome & 3.4 & circular & NZ_CP011832.1 \\
Plasmid & 0.32 & circular & NZ_CP011833.1 \\
\hline
\end{tabular}

The isolate was able to grow in a temperature range of 40 to $70{ }^{\circ} \mathrm{C}$ and $\mathrm{pH}$ of 5.5 to 9.0 , with a temperature optimum of $60{ }^{\circ} \mathrm{C}$ and a broad $\mathrm{pH}$ optimum between 6.5 and 8.0. Growth was observed in concentrations ranging between 0 and $5 \% \mathrm{NaCl}$. Besides aerobic growth, Geobacillus sp. 12AMOR1 was able to grow on yeast extract in anaerobic NRB medium containing nitrate [30].

Besides the utilization of starch, Geobacillus 12AMOR1 was able to grow on complex polysaccharides such as xylan, chitin and $\alpha$-cellulose (Table 1 ). Fast growth was accomplished by cultivating the isolate on yeast extract and gelatin. In addition, the isolate utilizes lactose, galactose and organic acids such as lactate and acetate. No growth was observed using pectine, xylose, tween 20 and tween 80 as carbon source. Geobacillus sp. 12AMOR1 degrades DNA supplemented in agar (Fig. 4d).

The strain produced acid, however no gas production was observed from the following carbohydrate substrates using API $50 \mathrm{CH}$ stripes and $\mathrm{CHB} / \mathrm{E}$ medium (BioMérieux, France): D-fructose, glycerol, esculin, Dmaltose, D-saccharose, D-trehalose, D-melezitose, amidon (starch), D-turanose, methyl- $\alpha \mathrm{D}$-glucopyranoside and potassium 5-ketogluconate. Weak acid was produced from

Table 4 Statistic of chromosomal genome, including nucleotide content and gene count levels

\begin{tabular}{lrc}
\hline Attribute & \multicolumn{1}{l}{ Value } & \% of total \\
\hline Genome size (bp) & $3,410,035$ & 100.00 \\
DNA coding (bp) & $2,936,125$ & 86.1 \\
DNA G + C (bp) & $1,775,346$ & \\
DNA scaffolds & 1 & \\
Total genes & 3,441 & 100.00 \\
rRNA operons & 10 & \\
rRNA genes & 29 & 0.83 \\
tRNA genes & 88 & 2.5 \\
tmRNA & 1 & 0.03 \\
Protein coding genes & 3,323 & 95.57 \\
Genes with function prediction & 2,454 & 70.58 \\
Genes assigned to COGs & 3,079 & 88.55 \\
Genes with signal peptids & 147 & 4.23 \\
Genes assigned to prophages & 92 & 2.65 \\
CRISPR repeats & 4 & \\
\hline
\end{tabular}


D-glucose, D-mannose, methyl- $\alpha \mathrm{D}$-mannopyranoside, $\mathrm{N}$ acetyl-glucosamine, D-lactose, D-melibiose, inulin, D-raffinose, glycogen, xylitol, (gentiobiose), D-lyxose and Dtagatose. In the API Zym panel (BioMérieux, France), strong activity was determined for alkaline phosphatase, esterase (C4), esterase/lipase (C8), leucine arylamidase, $\alpha$-chymotrypsin, acidic phosphatase and $\alpha$ glucosidase. Weak activity was observed for lipase (C14), valine arylamidase, cysteine arylamidase, naphtolAS-BI-phosphohydrolase, $\beta$-glucuronidase and $\beta$ glucosidase.

Geobacillus sp. 12AMOR1 was catalase positive using $3 \%$ hydrogen peroxide. Tests using diatabs (Rosco Diagnostics) identified the isolate as oxidase positive and urease negative.

\section{Genome sequencing information Genome project history}

The complete genome sequence and annotation data of Geobacillus sp. 12AMOR1 have been deposited in DDBJ/ EMBL/GenBank under the accession number CP011832.1. Sequencing was performed at the Norwegian Sequencing Centre in Oslo, Norway [31]. Assembly and finishing steps were performed at the Centre for Geobiology, University of Bergen, Norway. Annotation was performed using the Prokka automatic annotation tool [32] and manually edited to fulfill NCBI standards. Table 2 summarizes the project information and its association with MIGS version 2.0 compliance [33].

\section{Growth conditions and genomic DNA preparation}

A pure culture of the isolated Geobacillus sp. 12AMOR1 was cultivated on $50 \mathrm{ml} \mathrm{LB}$ media for $18 \mathrm{~h}$ at $60{ }^{\circ} \mathrm{C}$. After harvesting the cells by centrifugation at $8,000 \mathrm{x}$ g for 10 min high-molecular DNA for sequencing was obtained using a modified method of Marmur [34]. In short: The pellet was suspended in a solution of $1 \mathrm{mg} / \mathrm{ml}$ Lysozyme (Sigma 62971) in $10 \mathrm{mM} \mathrm{TE}$ buffer (pH 8) and incubated at $37^{\circ} \mathrm{C}$ for $15 \mathrm{~min}$. After a Proteinase $\mathrm{K}$ treatment $(40 \mathrm{mg} /$ $\mathrm{ml}$ final concentration, Sigma P6556) at $37^{\circ} \mathrm{C}$ for $15 \mathrm{~min}$, a final concentration of $1 \%$ SDS was added and the solution was incubated at $60{ }^{\circ} \mathrm{C}$ for 5 min until clearance of the solution. A final concentration of $1 \mathrm{M}$ sodium perchlorate (Sigma-Aldrich 410241) was added and the solution well mixed, before an equal volume of Phenol:Chloroform:Isoamylalcohol (25:24:1) was added and the solution gently

Table 5 Number of genes associated with general COG functional categories

\begin{tabular}{|c|c|c|c|}
\hline Code & Value & \%age ${ }^{a}$ & Description \\
\hline J & 146 & 4,4 & Translation, ribosomal structure and biogenesis \\
\hline A & 0 & 0 & RNA processing and modification \\
\hline K & 153 & 4,6 & Transcription \\
\hline L & 313 & 9,4 & Replication, recombination and repair \\
\hline B & 0 & 0 & Chromatin structure and dynamics \\
\hline $\mathrm{D}$ & 31 & 0,93 & Cell cycle control, cell division, chromosome partitioning \\
\hline V & 32 & 0,96 & Defense mechanisms \\
\hline $\mathrm{T}$ & 92 & 2,8 & Signal transduction mechanisms \\
\hline M & 123 & 3,7 & Cell wall/membrane/envelope biogenesis \\
\hline N & 41 & 1,2 & Cell motility \\
\hline$U$ & 31 & 0,93 & Intracellular trafficking, secretion, and vesicular transport \\
\hline O & 93 & 2,8 & Posttranslational modification, protein turnover, chaperones \\
\hline C & 136 & 4,1 & Energy production and conversion \\
\hline G & 127 & 3,8 & Carbohydrate transport and metabolism \\
\hline E & 230 & 6,9 & Amino acid transport and metabolism \\
\hline $\mathrm{F}$ & 65 & 1,9 & Nucleotide transport and metabolism \\
\hline $\mathrm{H}$ & 107 & 3,2 & Coenzyme transport and metabolism \\
\hline । & 80 & 2,4 & Lipid transport and metabolism \\
\hline P & 132 & 3,9 & Inorganic ion transport and metabolism \\
\hline Q & 17 & 0,5 & Secondary metabolites biosynthesis, transport and catabolism \\
\hline R & 0 & 0 & General function prediction only \\
\hline S & 1130 & 34 & Function unknown \\
\hline- & 244 & 7,3 & Not in COGs \\
\hline
\end{tabular}

${ }^{a}$ the total is based on the number of protein coding genes in the annotated genome 
shaken on a Vortexer for $10 \mathrm{~min}$. After centrifugation at $5,000 \mathrm{x}$ g for $10 \mathrm{~min}$ the upper phase was collected and the nucleic acids again extracted twice with Chloroform:Isoamylalcohol (24:1). The nucleic acids was precipitated with 2 volumes of ice cold $100 \%$ ethanol on ice for $60 \mathrm{~min}$, washed in $70 \%$ ethanol, dried and dissolved in $2 \mathrm{ml} \mathrm{solu}$ tion of $50 \mu \mathrm{g} / \mathrm{ml}$ RNase A (R6513 [Sigma]) in TE buffer for RNase treatment at $37^{\circ} \mathrm{C}$ for $30 \mathrm{~min}$. One deproteinizing step with Chloroform:Isoamylalcohol was performed as above. A final concentration of $0.3 \mathrm{M}$ Sodium Acetate $\mathrm{pH}$ 5.2 was added to the DNA solution and the DNA was precipitated using $100 \%$ ethanol as described above. The dried pellet was dissolved in $100 \mu \mathrm{l} 10 \mathrm{mM}$ Tris.HCL $(\mathrm{pH}=8)$ over night at $4^{\circ} \mathrm{C}$.

\section{Genome sequencing and assembly}

Approximately $200 \mu \mathrm{g}$ of genomic DNA was submitted for sequencing. In short, a library was prepared using $\mathrm{Pa}-$ cific Biosciences $10 \mathrm{~kb}$ library preparation protocol. Size selection of the final library was performed using BluePippin (Sage Science). The library was sequenced on Pacific Biosciences RS II instrument using P4-C2 chemistry. In total, two SMRT cells were used for sequencing. Raw reads were filtered and de novo assembled using SMRT Analysis v. 2.1 and the protocol HGAP v2 (Pacific Biosciences) [35]. The consensus polishing process resulted in a highly accurate self-overlapping contig, as observed using Gepard dotplot [36], with a length of 3,426,502 bp, in addition to a self-overlapping 45,474 bp plasmid. Circularization and trimming was performed using Minimus2 included in the AMOS software package [37]. The circular chromosomal contig and plasmid was polished and consensus corrected twice using the RS_Resequencing protocol in SMRT Analysis v. 2.1. The final polishing resulted in a 3,410,035 bp finished circular chromosome and a 32,689 bp circular plasmid, with a consensus concordance of $99.9 \%$. The chromosome was manually reoriented to begin at the location of the dnaA gene.

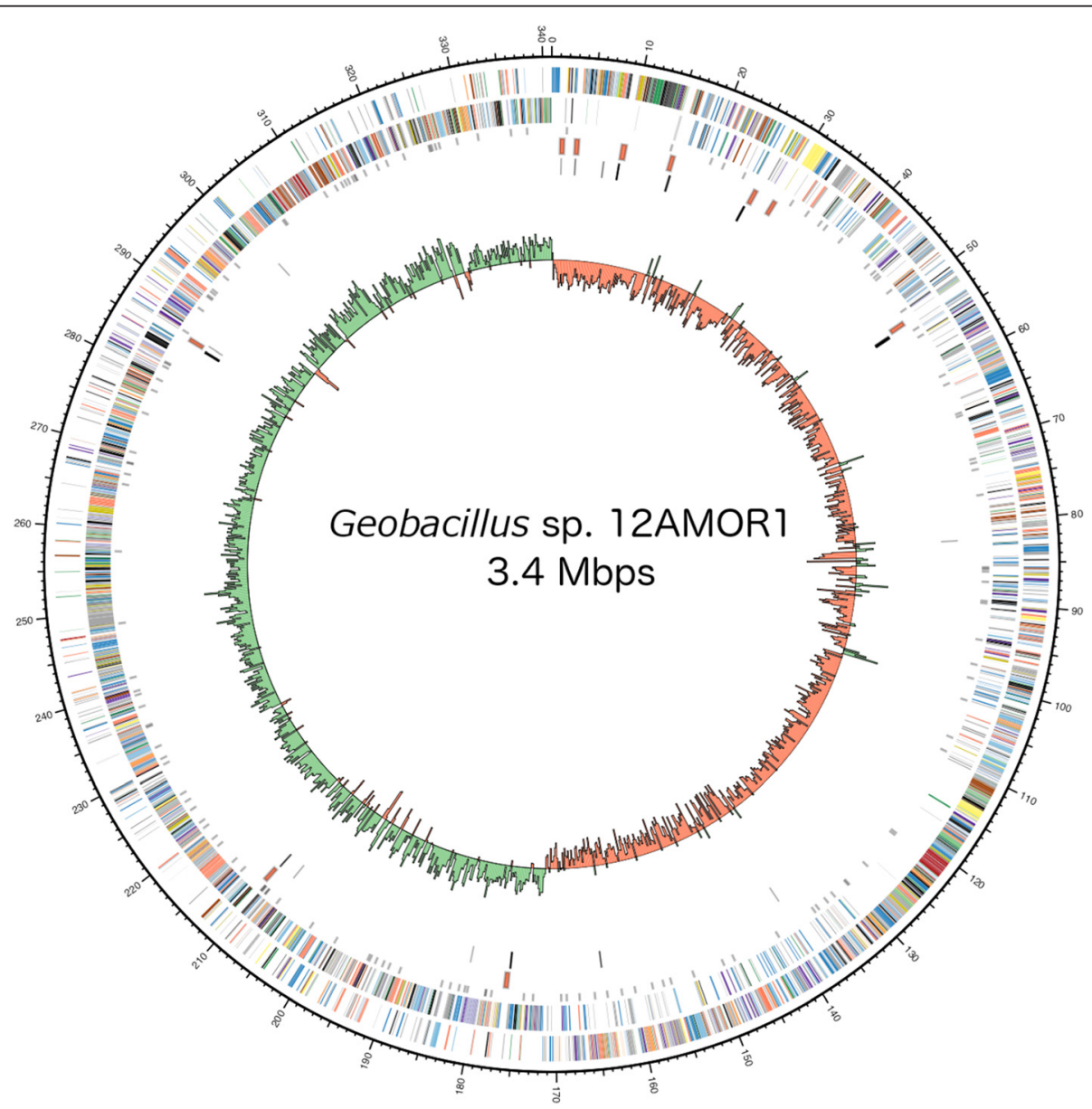

Fig. 3 Circular representation of the Geobacillus sp. 12AMOR1 draft genome displaying relevant genome features. Circles representing the following (from center to outside): 1, $\mathrm{G}+\mathrm{C}$ skew $[(\mathrm{G}-\mathrm{C}) /(\mathrm{G}+\mathrm{C})$ using a 2-kbp sliding window] (green, positive $\mathrm{G}+\mathrm{C}$ skew; red, negative $\mathrm{G}+\mathrm{C}$ skew); 2 , tRNAs (black); 3, rRNA operons (red); 4, CDS with signal peptides; 5, Coding DNA sequence (CDS) on the reverse strand; 6, CDS on the forward strand. Colour coding of CDS was based on COG categories. The figure was build using Circos version. 0.67-6 [54] 


\section{Genome annotation}

The protein-coding, rRNA, and tRNA gene sequences were annotated using Prodigal v. 2.6 [38], RNAmmer v. 1.2 [39] and Aragorn v. 1.2 [40] as implemented in the Prokka automatic annotation tool v. 1.11 [32].

\section{Genome properties}

The genome of Geobacillus sp. 12AMOR1 includes one plasmid of 32,689 bp (47\% G + C content), with one circular chromosome of 3,410,035 bp (52\% G + C content). The main chromosome contained 10 rRNA operons and 88 tRNAs and predicted to encode 3323 protein-coding genes (Table 3 and Fig. 3). 2454 of the protein-coding genes were assigned to a putative function. Identification of peptidases and carbohydrate-degrading enzymes was performed using the MEROPS peptidase database [41] and dbCAN [42], respectively. Using the PHAST web server for the detection of prophages [43], two prophage regions were detected, one intact $(56.1 \mathrm{~Kb}$ : $2476493-$ 2532633) and one incomplete (7.7 Kb: 28118722819623). $46 \%$ of the intact prophage protein-coding genes were related to the deep-sea thermophilic bacteriophage GVE2 (NC_009552). The 32.7 Kbps plasmid encoded 34 protein-coding genes.

\section{Insights from the genome sequence}

The genome of Geobacillus sp. 12AMOR1 encodes for 3323 protein-coding genes (Table 4). Of those proteins $26.15 \%$ could not be annotated towards a specific function and remain hypothetical. In total, $92.66 \%$ of the proteins could be assigned to a COG functional category. The COG functional categories included replication, recombination and repair (9.4\%); amino acid transport and metabolism (6.9\%); inorganic ion transport and metabolism (3.9\%); energy production and conversion (4.17\%); cell wall/membrane/envelop biogenesis $(3.7 \%)$ and carbohydrate transport and metabolism (3.8 \%) amongst others (Table 5). In the dbCAN analysis, 108 proteins were assigned for one or more functional activities within the CAZy families, which catalyzes the breakdown, biosynthesis or modification of carbohydrates and glycoconjugates [44, 45]. Geobacillus sp. 12AMOR1 hydrolyzes starch, dextrin, gelatin, casein and DNA, and utilized sugars such as D-glucose, Dgalactose, D-mannose, D-maltose, D-lactose, D-melibiose, D-saccharose, D-trehalose, D-raffinose and glycogen. CDSs encoding for enzymes to metabolize the above mentioned substrates were identified by genome prediction, homology search or mapping onto pathways using the KEGG Automatic Annotation Server [46] server.
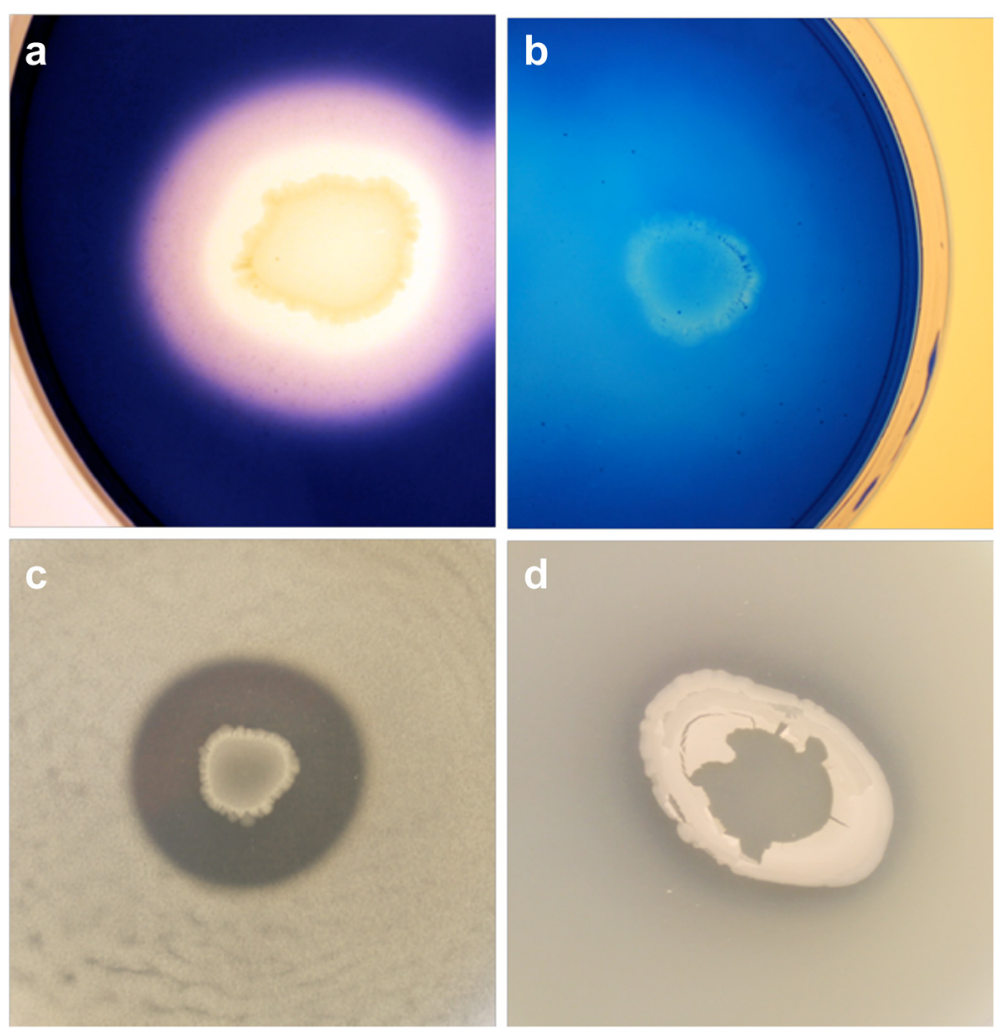

Fig. 4 Functional activity screening. Degradation halos around colonies of Geobacillus sp. 12AMOR1 growing on agar plates supplemented with a, starch; b, gelatin; c, skim milk and $\mathbf{d}$, DNA 
Table 6 Candidate genes coding for putative amylase, proteinase and DNase activities identified in Geobacillus sp. 12AMOR1 draft genome

\begin{tabular}{|c|c|c|}
\hline Putative gene & Annotation & Size (aa) \\
\hline \multicolumn{3}{|l|}{ Amylase } \\
\hline GARCT_00588 & alpha-amylase & 555 \\
\hline GARCT_00679 & Neopullulanase & 588 \\
\hline GARCT_00683 & alpha-amylase & 511 \\
\hline GARCT_01758 & Trehalose hydrolase & 563 \\
\hline GARCT_02913 & Glycogen debranching enzyme & 680 \\
\hline \multicolumn{3}{|l|}{ Glycosylases } \\
\hline GARCT_00799 & Lysozyme & 207 \\
\hline GARCT_00912 & Dextransucrase & 903 \\
\hline GARCT_01278 & putative polysaccharide deacetylase PdaA precursor & 327 \\
\hline GARCT_01944 & Rhamnogalacturonan acetylesterase RhgT & 279 \\
\hline GARCT_02324 & 6-phospho- $\beta$-glucosidase & 490 \\
\hline GARCT_03212 & Putative lysozyme/beta-N- acetylglucosaminidase precursor & 1279 \\
\hline GARCT_03220 & Putative lysozyme & 772 \\
\hline GARCT_03420 & Sucrose-6-phosphate hydrolase/GH32_beta_fructosidase & 481 \\
\hline \multicolumn{3}{|l|}{ Proteases } \\
\hline GARCT_00241 & Serine protease & 453 \\
\hline GARCT_00377 & Serine protease S01 & 401 \\
\hline GARCT_00795 & Oligoendopeptidase M03 & 607 \\
\hline GARCT_00799 & Peptidase M23 & 208 \\
\hline GARCT_00975 & Oligoendopeptidase M03 & 564 \\
\hline GARCT_01122 & Lon protease & 340 \\
\hline GARCT_01527 & Serine protease & 453 \\
\hline GARCT_01552 & Peptidase M32 & 500 \\
\hline GARCT_01840 & Oligoendopeptidase M03 & 618 \\
\hline GARCT_02099 & Aminopeptidase M29 & 413 \\
\hline GARCT_02390 & Dipeptidase M24 & 353 \\
\hline GARCT_02553 & ATP-dependent Clp proteolytic subunit & 244 \\
\hline GARCT_02603 & Protease & 422 \\
\hline GARCT_02604 & Peptidase U32 & 309 \\
\hline GARCT_02662 & Peptidase M23 & 256 \\
\hline GARCT_02693 & Lon protease 1 & 776 \\
\hline GARCT_02694 & Lon protease 2 & 558 \\
\hline GARCT_02769 & Aminopeptidase M42 & 362 \\
\hline GARCT_02850 & Aminopeptidase M42 & 358 \\
\hline GARCT_02860 & Putative dipeptidase & 471 \\
\hline GARCT_02867 & Neutral protease M04 & 548 \\
\hline GARCT_02978 & Aminopeptidase M17 & 497 \\
\hline GARCT_03009 & Peptidase M23 & 331 \\
\hline GARCT_03106 & ATP-dependent Clp proteolytic subunit & 197 \\
\hline GARCT_03137 & Serine protease $\$ 41$ & 480 \\
\hline GARCT_03221 & Thermitase & 875 \\
\hline GARCT_03224 & Stearolysin M4/S8 & 1338 \\
\hline
\end{tabular}


Table 6 Candidate genes coding for putative amylase, proteinase and DNase activities identified in Geobacillus sp. 12AMOR1 draft genome (Continued)

\begin{tabular}{|c|c|c|}
\hline GARCT_03453 & Trypsin-like serine protease & 407 \\
\hline \multicolumn{3}{|l|}{ DNase } \\
\hline GARCT_00042 & Putative Ribonuclease YcfH & 257 \\
\hline GARCT_00112 & Ribonuclease III C & 141 \\
\hline GARCT_00224 & Putative deoxyribonuclease $\mathrm{YcfH}$ & 251 \\
\hline GARCT_00623 & $3^{\prime}-5^{\prime}$ exoribonuclease YhaM & 326 \\
\hline GARCT_00659 & Nuclease SbcCd subunitD & 395 \\
\hline GARCT_01396 & Restriction endonuclease & 354 \\
\hline GARCT_01547 & Putative Exonuclease (hypothetical protein) & 421 \\
\hline GARCT_01867 & Extracellular ribonuclease & 309 \\
\hline GARCT_02076 & HNH endonuclease & 420 \\
\hline GARCT_02373 & Exodeoxyribonuclease VII, small subunit & 77 \\
\hline GARCT_02374 & Exodeoxyribonuclease VII, large subunit & 449 \\
\hline GARCT_02456 & Putative endonuclease 4 & 300 \\
\hline GARCT_02557 & HNH Endonuclease & 165 \\
\hline GARCT_02575 & HNH Endonuclease & 184 \\
\hline GARCT_02948 & Endonuclease YokF & 303 \\
\hline GARCT_03029 & Endonuclease YhcR & 461 \\
\hline
\end{tabular}

Furthermore, the isolate was able to grow on the complex carbon polymers xylan, chitin and $\alpha$-cellulose, however the pathways for such polymer degradation were not identified in the genome. In contrast, pathways for utilization of D-mannitol, arbutin and salicin were identified, although utilization involving acid production was not observed. In comparison with other Geobacillus strains, 12AMOR1 harbors less gene modules involved in hydrolysis and utilization of complex carbohydrates $[8,12]$.

Enzymes involved in protein degradation have been analyzed using MEROPS. In total 126 proteinases were identified. Of those 18 carried a signal peptide identified by SignalP [47] and could be responsible for the extracellular degradation of proteins. Geobacillus sp. 12AMOR1 showed strong enzymatic activities for esterase (C4), esterase/lipase (C8), leucine arylamidase, $\alpha$-chymotrypsin, $\alpha$-glucosidase, alkaline and acidic phosphatase and weak activity for lipase (C14), valine arylamidase, cysteine arylamidase, $\beta$-glucosidase, $\beta$-glucuronidase and naphtol-AS-BI-phosphohydrolase.

The Geobacillus sp. 12AMOR1 was screened for the following enzymatic activities; $\alpha$-amylases, gelatinases, caseinases, lipases, chitinases, xylanases [48-53] and DNase at $60{ }^{\circ} \mathrm{C}$. AG agar plates containing $0.1 \%(\mathrm{w} / \mathrm{v})$ yeast extract were used supplemented with $1 \%(\mathrm{w} / \mathrm{v})$ starch, $0.5 \%(\mathrm{w} / \mathrm{v})$ gelatin, $1 \%(\mathrm{w} / \mathrm{v})$ skim milk, $1 \%(\mathrm{v} / \mathrm{v})$ olive oil, $1 \%(\mathrm{v} / \mathrm{v})$ Tween20, $1 \%$ (v/v) Tween80, $0.5 \%$ $(\mathrm{w} / \mathrm{v})$ chitin, $0.5 \%(\mathrm{w} / \mathrm{v})$ xylan, respectively. DNase activity was screened on DNase Test Agar (Difco). The strain exhibited hydrolytic enzymatic activity for starch, gelatin, skin milk and DNA (Fig. 4). In addition, growth on plates containing olive oil, chitin and xylan were observed, however no hydrolytic activity could be detected. Putative genes encoding for $\alpha$-amylase, glycosylase, protease and DNase activity were identified in the genome based on annotation or by homology search (Table 6).

Due to their broad biotechnological applications, such as in food processing, detergents or bioethanol production [17], identifying novel $\alpha$-amylases is still of biotechnological interest. Five genes encoding for $\alpha$-amylases of the GH13 family (Table 6) were identified by dbCAN analysis. The neopullulanase (GARCT_00679; AKM17981) was cloned using following primers F: AGG AGA TAT ACC ATG CAA AAA GAA GCC ATT CAC CAC CGC, R: GTG ATG GTG ATG TTT CCA GCT TTC AAC TTT ATA GAG CAC AAA CCC, and expressed in E. coli BL21 (DE3). The protein GARCT_00679 was purified in high amounts from $E$. coli and revealed a melting temperature of $76.4{ }^{\circ} \mathrm{C}$ in differential scanning calorimetry (DSC) analysis. As expected this value was elevated from the optimal growth temperature of the isolate. Using purified protein solution on $1 \%$ starch-agar plates only GARCT_00679 showed starch degradation capacity comparable with the reference alpha amylase from $B$. licheniformis (Sigma-Aldrich) (Fig. 5). 


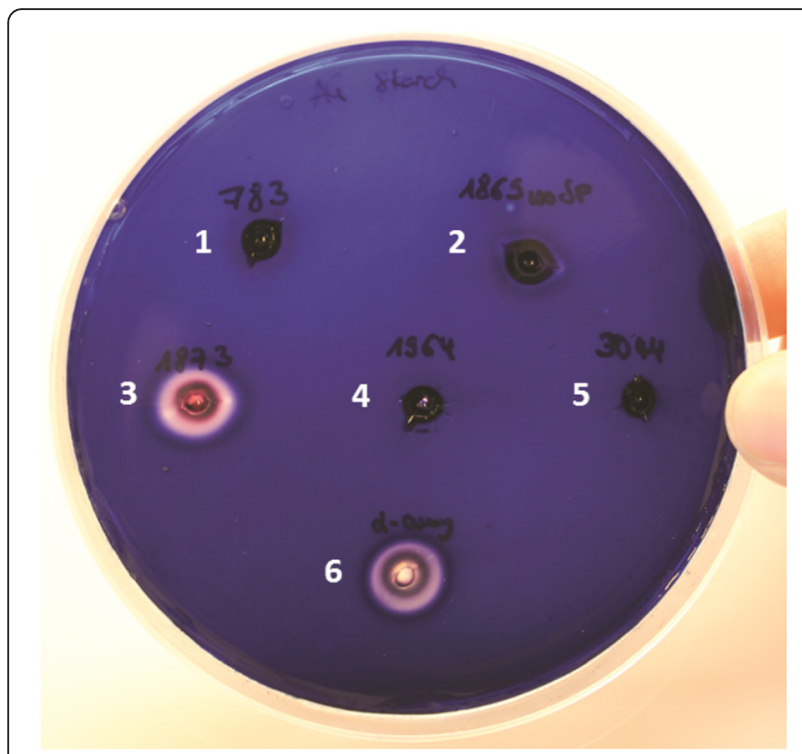

Fig. 5 Activity of purified Geobacillus sp. 12AMOR1 alpha-amylases on starch agar plates. As the plate was colored with iodine solution degradation appear as clear zones. 1) Trehalose hydrolase (GARCT_01758), 2) Alpha-amylase (GARCT_00683), 3) Neopullulanase (GARCT_00679), 4) Alpha-amylase (GARCT_00588), 5) Glycogen debranching enzyme (GARCT_02913), 6) Alpha-amylase from B. licheniformis (Sigma-Aldrich)

\section{Conclusions}

The starch degrading, thermophilic Geobacillus sp. 12AMOR1, isolated from an Arctic deep-sea hydrothermal vent system, revealed a 3.4 Mbp complete genome composed of a circular chromosome and a plasmid. The genome and plasmid have been deposited at GenBank under the accession numbers CP011832 and CP011833, respectively. The genome size within the genus ranges between 3.35 and 3.84 Mbp (RefSeq: NZ_BATY00000000.1; NC_014650.1), therefore Geobacillus. sp. 12AMOR1 belongs with $3.4 \mathrm{Mbp}$ to the smaller genomes. The $\mathrm{G}+\mathrm{C}$ content of $52 \%$ is within the average of the genus.

$16 \mathrm{~S}$ rRNA analysis identified the isolate belonging to Geobacillus stearothermophilus, whereas DDH analysis with 13 Geobacillus genomes indicated a slightly distant relationship towards the other Geobacillus strains. In the phylogenetic analysis Geobacillus sp. 12AMOR1 was located in a sub-cluster apart from the type strain G. stearothermophilus DSM $22^{\mathrm{T}}$ within in the same cluster.

When comparing the phenotypical characteristics of diverse G. stearothermophilus strains in the literature, the profile varies from strain to strain $[1,14,29]$. Most of the phenotypical features of Geobacillus sp. 12AMOR1 lie within those variations. Minor divergences of 12AMOR1 are acid production from potassium 5-ketogluconate and lactose (and maybe gentiobiose), utilization of lactose, and being oxidase positive. Those phenotypical characteristics are not sufficient to support a differentiation between $G$. stearothermophilus and Geobacillus sp. 12AMOR1, even though the DDH analysis suggests a distant relationship.

Although Geobacillus sp. 12AMOR1 features less genes encoding for carbohydrate degrading enzymes in comparison with other Geobacillus strains, a multiplicity of interesting enzymes, applicable for biotechnology, was identified by genome annotation and by activity screening. Hence, Geobacillus sp. 12AMOR1 can serve as a source of functional enzymes for future bioprospecting.

\section{Additional files}

Additional file 1: 16S rRNA sequence identities towards Geobacillus sp. 12AMOR1. Chosen blast hits with the highest sequence identity (98\%) towards the preliminary partial 16S rRNA gene of Geobacillus sp. strain 12AMOR1 using the megablast algorithm a standalone blastn [23] against $16 \mathrm{~S}$ ribosomal RNA (Bacteria and Archaea database). (DOCX 14 kb)

Additional file 2: Digital DNA-DNA Hybridization of Geobacillus sp.12AMOR1 genome towards other Geobacillus genomes performed by the Genome-to-Genome Distance Calculator (GGDC) 2.0 using formula 2 (identities/HSP length). The genomes of

G. kaustophilus HTA426 [NC_006510.1], G. stearothermophilus strain X1 [CP008855.1], G. stearothermophilus NUB3621 isolate 9A5 [CM002692.1], G. thermoleovorans CCB_US3_UF5 [CP003125.1], G. thermodenitrificans NG80-2 [NC_009328.1], G. vulcani PSS1 [gb|JPOI01000001.1], Geobacillus sp. C56-T3 [NC_014206.1], Geobacillus sp. GHH01 [CP004008.1], Geobacillus sp. JF8 [CP006254.2], Geobacillus sp. WCH70 [CP001638.1], Geobacillus sp. Y4.1MC1 [NC_014650.1], Geobacillus sp. Y412MC52 [NC_014915.1], Geobacillus sp. Y412MC61 [NC_013411.1] was used for comparison. The genome of Bacillus licheniformis ATCC $14580^{\top}$ [NC_006270.3] was used as outgroup. (PDF 67 kb)

\section{Abbreviations}

CAZy: Carbohydrate active enzyme; GH13: Glycoside hydrolase group 13; AG: Archaeoglobus medium.

\section{Competing interests}

The authors declare that they have no competing interests.

\section{Authors' contributions}

Conceived and designed the experiments: IHS, RS. Performed the isolation and characterization of the isolate: JW. Performed bioinformatics analysis and assembly refinement: RS. Analyzed the data: JW, RS and IHS. Performed enzyme expression, purification and characterization: JW, AEF, KL, AOS. Wrote the paper: JW, RS, HIS. All authors read and approved the final manuscript.

\section{Acknowledgements}

This work was funded by the Norwegian Research Council (Mining of a Norwegian biogoldmine through metagenomics, project 208491). We would like to acknowledge Frida-Lise Daae at the Centre for Geobiology, University of Bergen for technical assistance during nucleic acid extraction.

\section{Author details}

${ }^{1}$ Centre for Geobiology, University of Bergen, N-5020 Bergen, Norway. ${ }^{2}$ Department of Biology, University of Bergen, N-5020 Bergen, Norway. ${ }^{3}$ The Norwegian Structural Biology Center (NorStruct), Department of Chemistry, UIT - The Arctic University of Norway, 9037 Tromsø, Norway.

Received: 24 July 2015 Accepted: 16 February 2016

Published online: 24 February 2016

\section{References}

1. Nazina TN, Tourova TP, Poltaraus AB, Novikova EV, Grigoryan AA, Ivanova $A E$, et al. Taxonomic study of aerobic thermophilic bacilli: descriptions of Geobacillus subterraneus gen. nov., sp. nov. and Geobacillus uzenensis sp. nov. from petroleum reservoirs and transfer of Bacillus stearothermophilus, 
Bacillus thermocatenulatus, Bacillus thermoleovorans, Bacillus kaustophilus, Bacillus thermoglucosidasius and Bacillus thermodenitrificans to Geobacillus as the new combinations $G$. stearothermophilus, $G$. thermocatenulatus, $G$. thermoleovorans, G. kaustophilus, G. thermoglucosidasius and G. thermodenitrificans. Int J Syst Evol Microbiol. 2001;51(2):433-46.

2. Kato T, Haruki M, Imanaka T, Morikawa M, Kanaya S. Isolation and characterization of long-chain-alkane degrading Bacillus thermoleovorans from deep subterranean petroleum reservoirs. J Biosci Bioeng. 2001;91(1):64-70.

3. Marchant R, Banat IM, Rahman TJ, Berzano M. The frequency and characteristics of highly thermophilic bacteria in cool soil environments. Environ Microbiol. 2002;4(10):595-602.

4. Takami H, Inoue A, Fuji F, Horikoshi K. Microbial flora in the deepest sea mud of the Mariana Trench. FEMS Microbiol Lett. 1997;152(2):279-85.

5. Liu B, Wu S, Song Q, Zhang X, Xie L. Two novel bacteriophages of thermophilic bacteria isolated from deep-sea hydrothermal fields. Curr Microbiol. 2006;53(2):163-6.

6. Marchant R, Banat IM, Rahman TJ, Berzano M. What are high-temperature bacteria doing in cold environments? Trends Microbiol. 2002;10(3):120-1.

7. Logan NA, De Vos P, Dinsdale AE. Genus VII. Geobacillus. In: De Vos P, Garrity GM, Jones D, Krieg NR, Ludwig W, Rainey FA, Schleifer KH, Whitman WB, editors. Bergey's Manual of Systematic Bacteriology, The Firmicutes. 2nd ed. New York: Springer; 2009.

8. Zeigler DR. The Geobacillus paradox: why is a thermophilic bacterial genus so prevalent on a mesophilic planet? Microbiology-Sgm. 2014;160:1-11.

9. Inthanavong L, Tian F, Khodadadi M, Karboune S. Properties of Geobacillus stearothermophilus levansucrase as potential biocatalyst for the synthesis of levan and fructooligosaccharides. Biotechnol Prog. 2013;29(6):1405-15.

10. Jain I, Kumar V, Satyanarayana T. Applicability of recombinant beta-xylosidase from the extremely thermophilic bacterium Geobacillus thermodenitrificans in synthesizing alkylxylosides. Bioresour Technol. 2014;170:462-9.

11. Antranikian G, Vorgias CE, Bertoldo C. Extreme Environments as a Resource for Microorganisms and Novel Biocatalysts. Adv Biochem Engin/Biotechnol. 2005:96:219-62

12. Bhalla A, Kainth AS, Sani RK. Draft Genome Sequence of LignocelluloseDegrading Thermophilic Bacterium Geobacillus sp. Strain WSUCF1. Genome Announc. 2013;1(4).

13. Wang L, Tang Y, Wang S, Liu RL, Liu MZ, Zhang Y, et al. Isolation and characterization of a novel thermophilic Bacillus strain degrading long-chain n-alkanes. Extremophiles. 2006;10(4):347-56.

14. Nazina TN, Sokolova D, Grigoryan AA, Shestakova NM, Mikhailova EM, Poltaraus AB, et al. Geobacillus jurassicus sp. nov., a new thermophilic bacterium isolated from a high-temperature petroleum reservoir, and the validation of the Geobacillus species. Syst Appl Microbiol. 2005;28(1):43-53.

15. Espacenet Patent search. In: European Patent Office. http://worldwide. espacenet.com/.

16. Zeigler DR. The Genus Geobacillus - Introduction and Strain Catalog. In: Ohio State University DoB, The Bacillus Genetic Stock Center, editor. Bacillus Genetic Stock Center - Catalog of Strains, 7th Edition, Volume 3. 2001

17. de Souza PM, de Oliveira Magalhães P. Application of microbial alphaamylase in industry - A review. Braz J Microbiol. 2010;41(4):850-61.

18. Pedersen RB, Thorseth IH, Nygaard TE, Lilley MD, Kelley DS. Hydrothermal Activity at the arctic Mid-Ocean Ridges. Geophys Monogr. 2010;188:67-90.

19. Urich T, Lanzen A, Stokke R, Pedersen RB, Bayer C, Thorseth $\mathbb{H}$, et al. Microbial community structure and functioning in marine sediments associated with diffuse hydrothermal venting assessed by integrated metaomics. Environ Microbiol. 2014;16(9):2699-710.

20. Hocking WP, Stokke R, Roalkvam I, Steen IH. Identification of key components in the energy metabolism of the hyperthermophilic sulfate-reducing archaeon Archaeoglobus fulgidus by transcriptome analyses. Front Microbiol. 2014;5:95.

21. Edwards U, Rogall T, Blocker H, Emde M, Bottger EC. Isolation and direct complete nucleotide determination of entire genes. Characterization of a gene coding for 16S ribosomal RNA. Nucleic Acids Res. 1989;17(19):7843-53.

22. Lane DJ. 16S/23S rRNA sequencing. Nucleic acid techniques in bacterial systematics. Chichester: John Wiley and Sons; 1991

23. Altschul SF, Gish W, Miller W, Myers EW, Lipman DJ. Basic local alignment search tool. J Mol Biol. 1990;215(3):403-10.

24. Edgar RC. MUSCLE: a multiple sequence alignment method with reduced time and space complexity. BMC Bioinformatics. 2004;5:113.

25. Edgar RC. MUSCLE: multiple sequence alignment with high accuracy and high throughput. Nucleic Acids Res. 2004;32(5):1792-7.
26. Tamura K, Stecher G, Peterson D, Filipski A, Kumar S. MEGA6: Molecular Evolutionary Genetics Analysis version 6.0. Mol Biol Evol. 2013;30(12):2725-9.

27. Auch AF, von Jan M, Klenk HP, Goker M. Digital DNA-DNA hybridization for microbial species delineation by means of genome-to-genome sequence comparison. Stand Genomic Sci. 2010;2(1):117-34.

28. Powers EM. Efficacy of the Ryu nonstaining $\mathrm{KOH}$ technique for rapidly determining gram reactions of food-borne and waterborne bacteria and yeasts. Appl Environ Microbiol. 1995;61(10):3756-8.

29. Coorevits A, Dinsdale AE, Halket G, Lebbe L, De Vos P, Van Landschoot A, et al. Taxonomic revision of the genus Geobacillus: emendation of Geobacillus, G. stearothermophilus, G. jurassicus, G. toebii, G. thermodenitrificans and G. thermoglucosidans (nom. corrig., formerly 'thermoglucosidasius'); transfer of Bacillus thermantarcticus to the genus as G. thermantarcticus comb. nov:; proposal of Caldibacillus debilis gen. nov., comb. nov.; transfer of $G$. tepidamans to Anoxybacillus as A. tepidamans comb. nov.; and proposal of Anoxybacillus caldiproteolyticus sp. nov. Int J Syst Evol Microbiol. 2012;62(7): 1470-85.

30. Myhr S, Torsvik T. Denitrovibrio acetiphilus, a novel genus and species of dissimilatory nitrate-reducing bacterium isolated from an oil reservoir model column. Int J Syst Evol Microbiol. 2000;50(Pt 4):1611-9.

31. The Norwegian Sequencing Centre (NSC). https://www.sequencing.uio.no/.

32. Seemann T. Prokka: rapid prokaryotic genome annotation. Bioinformatics. 2014;30(14):2068-9.

33. Field D, Garrity G, Gray T, Morrison N, Selengut J, Sterk P, et al. The minimum information about a genome sequence (MIGS) specification. Nat Biotechnol. 2008;26(5):541-7.

34. Marmur J, Doty P. Thermal Renaturation of Deoxyribonucleic Acids. J Mol Biol. 1961;3(5):585.

35. Chin C-S, Alexander DH, Marks P, Klammer AA, Drake J, Heiner C, et al. Nonhybrid, finished microbial genome assemblies from long-read SMRT sequencing data. Nat Meth. 2013;10(6):563-9.

36. Krumsiek J, Arnold R, Rattei T. Gepard: a rapid and sensitive tool for creating dotplots on genome scale. Bioinformatics. 2007;23(8):1026-8.

37. Treangen TJ, Sommer DD, Angly FE, Koren S, Pop M. Next Generation Sequence Assembly with AMOS. Curr Protoc Bioinformatics. 2011;CHAPTER 11:Unit 11.8. doi:10.1002/0471250953.bi1108s33.

38. Hyatt $\mathrm{D}$, Chen GL, Locascio PF, Land ML, Larimer FW, Hauser LJ. Prodigal: prokaryotic gene recognition and translation initiation site identification. BMC Bioinformatics. 2010:11:119.

39. Lagesen K, Hallin P, Rodland EA, Staerfeldt HH, Rognes T, Ussery DW. RNAmmer: consistent and rapid annotation of ribosomal RNA genes. Nucleic Acids Res. 2007:35(9):3100-8.

40. Laslett D, Canback B. ARAGORN, a program to detect tRNA genes and tmRNA genes in nucleotide sequences. Nucleic Acids Res. 2004;32(1):11-6.

41. Rawlings ND, Morton FR. The MEROPS batch BLAST: a tool to detect peptidases and their non-peptidase homologues in a genome. Biochimie. 2008;90(2):243-59.

42. Yin Y, Mao X, Yang J, Chen X, Mao F, Xu Y. dbCAN: a web resource for automated carbohydrate-active enzyme annotation. Nucleic Acids Res. 2012 40(Web Server issue):445-51.

43. Zhou Y, Liang Y, Lynch KH, Dennis JJ, Wishart DS. PHAST: a fast phage search tool. Nucleic Acids Res. 2011:39(Web Server issue):347-52.

44. Cantarel BL, Coutinho PM, Rancurel C, Bernard T, Lombard V, Henrissat B. The Carbohydrate-Active EnZymes database (CAZy): an expert resource for Glycogenomics. Nucleic Acids Research. 2009;37:D233-D8.

45. Lombard V, Ramulu HG, Drula E, Coutinho PM, Henrissat B. The carbohydrate-active enzymes database (CAZy) in 2013. Nucleic Acids Research. 2014;42(D1):D490-D5.

46. Moriya Y, Itoh M, Okuda S, Yoshizawa AC, Kanehisa M. KAAS: an automatic genome annotation and pathway reconstruction server. Nucleic Acids Res. 2007;35:W182-W5.

47. Petersen TN, Brunak S, von Heijne G, Nielsen H. SignalP 4.0: discriminating signal peptides from transmembrane regions. Nature Methods. 2011;8(10):785-6.

48. Teather RM, Wood PJ. Use of Congo red-polysaccharide interactions in enumeration and characterization of cellulolytic bacteria from the bovine rumen. Appl Environ Microbiol. 1982:43(4):777-80.

49. Kasana RC, Salwan R, Dhar H, Dutt S, Gulati A. A Rapid and Easy Method for the Detection of Microbial Cellulases on Agar Plates Using Gram's lodine. Curr Microbiol. 2008;57(5):503-7. 
50. Vaidya RJ, Macmil SL, Vyas PR, Chhatpar HS. The novel method for isolating chitinolytic bacteria and its application in screening for hyperchitinase producing mutant of Alcaligenes xylosoxydans. Lett Appl Microbiol. 2003;36(3):129-34.

51. Lee DG, Jeon JH, Jang MK, Kim NY, Lee JH, Lee JH, et al. Screening and characterization of a novel fibrinolytic metalloprotease from a metagenomic library. Biotechnol Lett. 2007;29(3):465-72.

52. Vermelho AB, Meirelles MN, Lopes A, Petinate SD, Chaia AA, Branquinha MH Detection of extracellular proteases from microorganisms on agar plates. Mem Inst Oswaldo Cruz. 1996;91(6):755-60.

53. Berlemont R, Pipers D, Delsaute M, Angiono F, Feller G, Galleni M, et al. Exploring the Antarctic soil metagenome as a source of novel cold-adapted enzymes and genetic mobile elements. Rev Argent Microbiol. 2011;43(2):94-103.

54. Krzywinski MI, Schein JE, Birol I, Connors J, Gascoyne R, Horsman D, et al. Circos: An information aesthetic for comparative genomics. Genome Res. 2009;19(9):1639-45.

55. Woese CR, Kandler O, Wheelis ML. Towards a natural system of organisms: proposal for the domains Archaea, Bacteria, and Eucarya. Proc Natl Acad Sci U S A. 1990;87(12):4576-9.

56. Gibbons NE, Murray RGE. Proposals Concerning the Higher Taxa of Bacteria. Int J Syst Bacteriol. 1978;28(1):1-6.

57. Schleifer KH. In: De Vos P, Garrity GM, Jones D, Krieg NR, Ludwig W, Rainey FA, Schleifer KH, Whitman WB, editors. Bergey's Manual of Systematic Bacteriology, The Firmicutes. 2nd ed. New York: Springer; 2009. p. 19.

58. List of new names and new combinations previously effectively, but not validly, published. Int J Syst Evol Microbiol. 2010;60(3):469-72.

59. Ludwig W, Schleifer KH, Whitman WB. Class I. Bacilli class. nov. In: De Vos P, Garrity GM, Jones D, Krieg NR, Ludwig W, Rainey FA, Schleifer KH, Whitman WB, editors. Bergey's Manual of Systematic Bacteriology, The Firmicutes. 2nd ed. New York: Springer; 2009. p. 19-20.

60. Prévot AR, Prévot AR. In: Hauderoy PEG, Guillot G, Hauderoy PEG, Guillot G, Magrou J, Prévot AR, Rosset D, Urbain A, editors. Dictionnaire des Bactéries Pathogènes. 2nd ed. Paris: Masson et Cie; 1953. p. 1-692.

61. Skerman V, McGowan V, Sneath P. Approved Lists of Bacterial Names. Int J Syst Evol Microbiol. 1980;30(1):225-420.

62. Fischer A. Untersuchungen über bakterien. Jahrbücher für Wissenschaftliche Botanik. 1895;27:1-163.

63. Ashburner M, Ball CA, Blake JA, Botstein D, Butler H, Cherry JM, et al. Gene ontology: tool for the unification of biology. The Gene Ontology Consortium. Nat Genet. 2000;25(1):25-9.

\section{Submit your next manuscript to BioMed Central and we will help you at every step:}

- We accept pre-submission inquiries

- Our selector tool helps you to find the most relevant journal

- We provide round the clock customer support

- Convenient online submission

- Thorough peer review

- Inclusion in PubMed and all major indexing services

- Maximum visibility for your research

Submit your manuscript at www.biomedcentral.com/submit

C Biomed Central 